\title{
Entrepreneurial Characteristics and Competency as Determinants of Business Performance in SMEs
}

\author{
Endi Sarwoko ${ }^{1}$, Surachman $^{2}$, Armanu $^{3}$, Djumilah Hadiwidjojo 4 \\ 1,2,3,4 (Economics and Business Faculty, University of Brawijaya, Indonesia)
}

\begin{abstract}
The purpose of this research is to empirically test the influence of entrepreneurial characteristics and competencies on business performance in small and medium enterprises (SMEs). This study was conducted with 147 SMEs owner in Malang regency East Java Indonesia using survey instrument. Data analysis using the Structural Equation Modelling. The results of this study indicate that the entrepreneurial characteristics have a significant influence on business performance. Entrepreneurial competencies as mediating in the relationship between entrepreneurial characteristics and business performance. It means the more powerful entrepreneurial characteristics will lead to an increase in the competence of the SMEs owner, which will ultimately have an effect on business performance.
\end{abstract}

Keywords - entreprenurial characteristics, competencies, business performance

\section{INTRODUCTION}

Small business growth is a complex and multidimensional in scope and character. It includes the convergence of ambition owner/manager, competence, internal factors organization, the resources and infrastructure, external relations and networking (Shaw and Conway, 2000). Factors influence the success of SMEs important to know because it is the low level of business success. SMEs have important contribution to create new jobs, trade, and country's Gross Domestic Product (GDP).

Research on the factors that affect the business performance of small and medium enterprises can be classified into two groups which focus on the aspects of personal and group that focus on aspects of the organization. Research with the focus on the aspects of personal emphasis on the entrepreneurial individual factors, such as individual characteristics, demographic factors, competencies. While the study focused on organizational aspects include the resources of the organization, the company's competence, organizational culture, and structure. Research on personal factors that affect business performance can be classified into 4 groups (Li, 2009), namely: 1) personal characteristics, included in this group are the research that focus on the nature and the motives of self-employment that distinguishes self-employment with the entrepreneurial, not 2) psyschological characteristics, emphasizing on the importance of individual characteristics, such as the need for achievement, internal locus of control, take risks, creativity, and innovation, 3) human capital, such as level of education, work experience, experience, skills and technical knowledge, as well as 4) behavioral approaches that suggest competence to identify and define the characteristics of a successful manager. Then $\mathrm{Li}$ (2009) argue that personal factors influence business success in SMEs consists of personality traits and competencies of the individuals in the process of entrepreneurship.

Study on personality traits often conducted to examine the factors that determine the business success at small business are the characteristics of an entrepreneur. Some studies have revealed that the performance of small business is determined by the characteristics of the owner/manager (Lee dan Tsang, 2001; Solichin, 2005; Blackman, 2003; O’Regan et al., 2005; Zoya dan Herath, 2007; Kotey dan Meredith, 1997; Nimalathasan, 2008; Man et al., 2002; Kiggundu, 2002; Ahmad et al., 2010; Man \& Wafa, 2008), all claims that owners/manager is the key factor the performance of a business. Research focus on competency factors trying to test how the influence of competency to the business performance. Kiggundu (2002) argue that the overall entrepreneurial competencies are attributes of entrepreneurship which include attitudes, beliefs, knowledge, skills, abilities, personality, and behavior which is directed to achieve success. Further stated that entrepreneurial competencies could offer unrealistic views about how somebody know running a business. Ahmad et al. (2010) found that entrepreneurial competencies as predict the success of the business of SMEs in Malaysia, even his influence stronger to environmental conditions that is stable and dynamic. Study of Man and Lau (2005) showing that entrepreneurial competencies influential significant for the success of the business..

Although few studies have tested empirically the factors that affect the performance of SMEs, and it has been proved that entrepreneurial characteristics and competencies are the factors that affect business performance, is still few research that examines the relationship between entrepreneurial characteristics with entrepreneurial competencies or test the role of entrepreneurial competencies as a mediating link between entrepreneurial characteristics and business performance. This study attempts to empirical test the impact of entrepreneurial characteristics on business performance is mediated by the entrepreneurial competencies. This 
paper is organized as follows. In the following section we begin with literature review, methodology, followed by the empirical examination of research questions.

\subsection{Entrepreneurial Characteristics}

\section{LITERATURE REVIEW}

Hisrich et al. (2008) divides entrepreneurial characteristics include: education, personal values, age, work experience, moral support network, and professional support network. According to Sorensen and Chang (2006) entrepreneurial characteristics that determine the business success to include:

1. Psychological factors

Psychology factor is a characteristic of the individual as well as in the literature of psychology.

Psychological factors that affect business performance includes need for achievement, locus of control, and personal traits.

2. Education and experience

Level of education founder/owner business positively associated with busines performance. Higher education is considered to have a better impact in entrepreneurship because it reflects the fact that they average more capable.

The characteristics of entrepreneur into two types (Blackman, 2003), namely:

1. Attribute

Attribute is characteristic owned entrepeneur includes: age, gender, religion, the influence of the family (family influence)

2. Attained

Attained qualifications include education, and business experience

Establishment of the entrepreneur's character is influenced by a number of internal and external factors, namely the environment, education, personal values, and work experience (Shane et al., 2003).

\subsection{Entrepreneurial Competency}

Entrepreneurial competencies is defined as the individual characteristics including attitude and behavior, which allows the entrepreneur to achieve business success. In particular entrepreneurial competencies include entrepreneurial traits, motives, self-image, attitude, behavior, skills, and knowledge (Boyatzis, 1982). Competencies can be learned from the input (antecedent of competence), processes (task or behavior that lead to competence), or result (achieving a standard of competence in the field of functional) (Shane et al., 2003).

Man (2001) recommend components for measuring entrepreneurial competencies: strategy, commitment, conceptual, opportunity, relationship, learning, personal.

1. Strategy Competency

Develop vision and strategy, plan ahead, set goals and standards, sell ideas.

2. Commitment

Demonstrate strong motivation to compete, drive to see venture through to fruition, capacity to make an impact, drive and dedication

3. Conceptual Competency

Demonstrate the possession of cognitive ability and decision-making skill, ability to weigh risks, think analytically, be innovative, be creative, show reasoning, capacity to reduce risks.

4. Opportunity Competency

Ability to recognise opportunity, ability to capture opportunity, ability to identify customers need.

the customer wants

5. Relationship Competency

Possess and use good interpersonal and communication skills, ability to influence others and gain support.

6. Organising CompetencyAbility to direct, lead, delegate, motivate, plan and schedule work, develop program, prepare budget.

Personal Competency

Recognise and work on own shortcomings, maintain a high level of energy, respond to constructive criticism, prioritise tasks to manage time, manage own career development, motivate myself to function at an optimum level of performance, identify strengths and weaknesses and match them with opportunities and threats

7. Learning Competency

Learn as much as I can in my field, learn from a variety of means, learn proactively, keep up to date in my field, apply learned skills and knowledge to actual practices

Ahmad et al. (2010) using the measurement of entrepreneurial competence covering: srategic, conceptual, opportunity, relationship, learning, personal, ethical, familism.

1. Strategic 
Monitor progress toward strategic goals, prioritise work in alignment with business goals, identify longterm issues, problems or opportunities, align current actions with strategic goals, evaluate results against strategic goals, redesign business to better meet long-term objectives, determine strategic actions by weighing costs and benefits

2. Conceptual

Explore new ideas, take reasonable job-related risks, treat new problems as opportunities, monitor progress toward objectives in risky actions, understand the broader business implications of ideas, issues and observations

3. Opportunity

Perceive unmet consumer needs, seize high quality business opportunities, actively look for products or services that provide real benefit to customers, identify goods or services that the customer wants

4. Relationship

Negotiate with others, maintain a personal network of work contacts, interact effectively with others, develop long-term trusting relationships with others, promote teamwork

5. Learning

Learn as much as I can in my field, learn from a variety of means, learn proactively, keep up to date in my field, apply learned skills and knowledge to actual practices

6. Personal

Recognise and work on own shortcomings, maintain a high level of energy, respond to constructive criticism, prioritise tasks to manage time, manage own career development, motivate myself to function at an optimum level of performance, identify strengths and weaknesses and match them with opportunities and threats

7. Ethical

Admit mistakes and tell the truth, be honest and transparent in business dealings, be committed to offering products/services at fair prices, take responsibility and be accountable for own actions

8. Familism

Cooperate with and help others in business (especially close associates), identify and seek help from employees that can be trusted, get support and advice from family and close associates, share knowledge and resources with others (especially close associates)

\subsection{Business Performance}

Business performance can be seen from the level of sales, profitability, rate of return of capital, the rate of turnover and gained market share (Jauch and Glueck, 1998). Li et al. (2005) uses 3 indicators for performance measurement of efficiency, growth, and profit. The business performance is the phenomenon of multiple aspects that are difficult to quantify (Sanchez and Marin, 2005). A variety of the literature shows that both quantitative and qualitative indicators have limitations and are recommended to be used interchangeably. Measuring quantitatively such as ROI, profit, sales, and so on. While the qualitative measurements are often called as performance indicators, performance measurement is by using the approach a certain scale of performance variables such as knowledge and business experience, the ability to offer quality products and services, the capacity to develop new products and processes, the ability to manage and work in groups, labor productivity, and corporate responsibility to the environment. Carnison in Sanchez and Marin (2005) measured the performance of small and medium enterprises with reference to the three aspects namely profitability, productivity, and market. While Lee and Tsang (2001) using performance effort represented by the growth venture consisting of sales growth, the growth of the company's assets, and profit growth. Studies in small and medium enterprises, business performance measurement approach typically uses a mixture of (financial and non financial), but difficulties arose three managers or owners of small and medium enterprises are not willing or object to provide information a robust performance data (Beal, 2000).

\subsection{Entrepreneurial Characteristics and Business Performance}

Entrepreneurs having the characteristics of varying and practices vary; therefore important to understand the relation between characteristic owner/manager with performance. Previous result shows that performance small-business determined by owner/manager personal value (Zoysa dan Herath, 2007; Lee and Tsang, 2001; Street and Cameron, 2007; Nimalathasan, 2008; Solichin, 2005). All of which stated that the owners/manager is a key factor in business performance. Zoysa and Herath (2007) examined the relationships among owner/manager with business performance at different stages of business growth, when owner/managers of SMEs are more entrepreneurial minded in the introductory and decline stages of growth, their performance tends to be higher, and the same is true for the growth and maturity stages when they are more administrative minded. This suggests that owner managers need to become more entrepreneurial oriented in their strategies and actions in order to achieve better performance in the introductory and decline stages. Conversely, they need to 
be more administrative oriented to achieving better results in the growth and maturity stages. Lee and Tsang (2001) reported that the experience, job network development activities, the number of business partners, the desire manages to have a positive impact on business growth. Solichin (2005) proved that the entrepreneurial characteristics have a meaningful influence on business growth, as well as business climate variables have an influence that meaningful progress toward the effort.

Street and Cameron (2007) reported that the performance/business success is determined by several factors, namely: individual characteristics, organizational characteristic. Zoysa and Herath (2007) show that there is a relationship between mental owner/manager with a performance at different stages of business growth, supported by Nimalathasan (2008) argue the existence of a positive relationship between the characteristics of the owner/manager with business performance.

H1. A higher level of entrepreneurial characteristics will be a greater business performance in SMEs

\subsection{Entrepreneurial Characteristics and Competency}

Fagenson (1993) argued that values exert a strong influence on an individual's vocational behaviour. The specific behaviour of interest in this paper is the behaviour of owner-managers in small firms. Accordingly, a key factor in the creation and implementation of strategy in small businesses is the determining influence of the owner-manager's values (Olson and Currie, 1992). Boytazis (1982) argues that the characteristics which lead to competence consists of one's motives, traits, aspects of the role of a person's self image or social skills, and knowledge are used. So the role of entrepreneurial behaviour attributes will be determined by the competence, competence will act as mediating the relationship attribute with entrepreneurial behavior. Herron and Robinson (1993) argue that the experience of employers, training, education, family background and other demographic variables are considered as factors affecting entrepreneurial competencies. This indicates the existence of a relationship between entrepreneurial characteristics and competencies of the company.

\subsection{Entrepreneurial Competency and Business Performance}

Business success will be influenced by the skill and the ability (competence) of the owner/manager. Understand the role of entrepreneur gives a better insight about what competencies needed by entrepreneurs to ensure the survival of the business as well as business success. The role of decision makers is focusing on the development of entrepreneurial competencies (Akhmad et al., 2010). Kiggundu (2002) conceptualises entrepreneurial competencies as the total sum of entrepreneurs attributes such as attitudes, beliefs, knowledge, skills, abilities, personality, expertise and behavioural tendencies needed for success and sustaining entrepreneurship. An in-depth analysis of entrepreneurial competencies saw competencies of

entrepreneurs as having dual origins: first, components that are more deeply rooted in the entrepreneur's background (i.e. traits, personality, attitudes, self image, and social roles) and second, components that could be acquired at work or through theoretical or practical learning (i.e. skills, knowledge, and experience).

Entrepreneurial competencies influence significantly to business success (Man et al., 2002), Ahmad et al. (2010) argues that entrepreneurial competencies as a predictor of business success SMEs in Malaysia, even its influence more strongly for stable environmental conditions as well as dynamically.

The capabilities and characteristics of the personality of those who manage companies universally regarded as one of the most powerful factors have a positive or negative impact on performance (Zoysa and Herath, 2007). Ability to demonstrate the competence of the owner/manager of a small business, where the competence of that will be affected by entrepreneurial characteristics of the respective owners/managers.

H2. The entrepreneurial competencies significantly mediation the relationship between entrepreneurial characteristics and business performance in SMEs

This study examines the influence entrepreneurial characteristics on business performance, and influence entrepreneurial competencies on business performance with mediated by entrepreneurial competency.

\subsection{Sample}

\section{METHODOLOGY}

The definition of SMEs provided by Department of Cooperatives, Small and Medium Enterprises Indonesian were used to identify appropriate businesses for inclusion in the study. The final sample of respondent in this study included 147 SMEs owner in the Malang regency, East Java, Indonesia.

\subsection{Data Collection Methods}

In this study data was collected using structured questionnaires. The survey focuses on the SMEs owner, a total of 147 owners were selected from various SMEs. The questionnaire was adopted from previous sources. The variables selected in this study are entrepreneurial characteristics, entrepreneurial competencies, business performance. Items selected to measure these variables were adopted from previous studies. All the variables were measured using five point likert scale with level $1=$ strongly disagree and $5=$ strongly agree. 


\subsection{Measurement}

\section{Entrepreneurial Characteristics}

Entrepreneurial characteristics are characteristic of small and medium business owners. Measurement of the characteristics of the owner in this study adopted from Sorensen \& Chang (2006) and Blackman (2003), includes three indicators as follows:

a. Psychological factors, characteristic of individuals which include the need for achievement, and motivation.

b. Experience, level experience in performing business or experience in this whole business.

c. Family influence, the intensity of the family influence in decision-making, and the role of family background.

2. Entrepreneurial competency

Entrepreneurial competencies are overall attributes (abilities and skills) owned business owners (Kiggundu, 2002). Entrepreneurial competency measures adopted of Man (2001) by using the indicator: conceptual competency, opportunity competency, relationship competency, learning competency, personal competency.

3. Business Performance

Business performance in this research is the perception of the owners or managers about business performance compared to the goals want to achieve. Business performance measures adopted of Lee \& Tsang (2001) consists of three indicators: sales growth, profit growth, and capital growth.

\subsection{Method of Data Analysis}

Data analysis in this research using Structural Equation Modelling (using AMOS 6). SEM is a combination of two statistical methods of factor analysis and path analysis into one comprehensive statistical methods. Structural equation modelling consists of a two-part 1) measurement of the part that relates the observed variable with variable latent through confirmatory factor analysis, and structural part 2) that relationship between variable latent with regression simultaneous (Ghozali, 2005).

\section{RESUlt}

As many as 147 SMEs owners who examined consists of 80.3 percent of men and 26.4 percent of women. The categories of respondents based on the age of majority is set at the age of 30-40 years is as much as 58,50 percent, over 40 years 30.61 percent, and 10.88 percent less than 30 years. As much as owners 89,8 percent of the SMEs had business experience over 5 years, 10.2 percent of her business experience less than 5 years.

Confirmatory factor analysis (CFA) is used to test the reliability of unidimensional and construct validity. Testing the significance of the loading indicator to see the value of critical ratio, if the value of the critical ratio is greater than the critical value at the 0.05 level of significance (critical values $=1.96$ ) then the indicators significantly is an indicator of construct validity formed (Ghozali, 2005). Evaluation of reliability construct uses the value of the level of reliability that is received is 0.7 (Ferdinand, 2006). Table 1 shows the test results are constructs reliability unidimensional and show proof of reliability is good.

Table 1. Construct reliability analysis

\begin{tabular}{lccc}
\hline \multicolumn{1}{c}{ Construcs and item } & Standardized Loading & CR & Reliability \\
\hline Entrepreneur characteristics & & & 0.899 \\
CE1 & 0.954 & & \\
CE2 & 0.840 & 13.354 & \\
CE3 & 0.794 & 12.268 & 0.897 \\
Entrepreneurial competency & & & \\
EC1 & 0.791 & 10.379 & \\
EC2 & 0.793 & 12.103 & \\
EC3 & 0.905 & 10.050 & \\
EC4 & 0.773 & 9.159 & 0.883 \\
EC5 & 0.717 & & \\
Business Performance & & & \\
BP1 & 0.822 & 11.355 & \\
BP2 & 0.892 & 10.838 & \\
BP3 & 0.822 & & \\
\hline
\end{tabular}

The results of the analysis in table 1 shows a reliability test for each construct. Standardized loading at all constructs which analyzed is greater than 0.7 , and statistically significant for $p<0.05$. This result shows that evidence of indicators that used to have the validity of convergent for use in this study. 
Before testing the structural model estimation, performed evaluations on goodness of fit. Evaluation of goodness of fit found $\mathrm{X}^{2}=78.656$; prob. $=0.000 ; \mathrm{CMIN} / \mathrm{df}=1.918, \mathrm{RMSEA}=0.079, \mathrm{GFI}=0.901, \mathrm{CFI}=0.965$ dan TLI $=0.952$. Based on the results of testing goodness of fit where CMIN/DF, RMSEA, GFI, TLI and CFI have met the criteria then it can be inferred that the model meets the conformance model.

After testing the model of measurement and testing structural equation models the overall fit, the next step is to test the relationship between constructs which were built according to the proposed hypothesis.

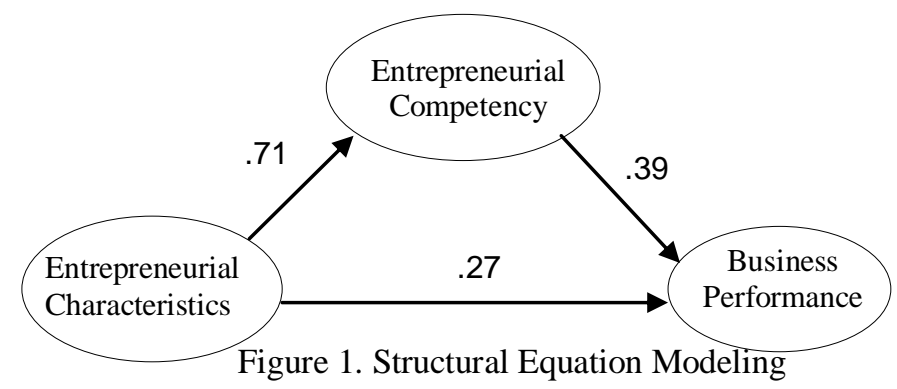

Table 2. Path Coefficient

\begin{tabular}{lcc}
\hline Path & Coefficient & P \\
\hline Entrepreneurial Characteristics $\rightarrow$ Business Performance & 0.269 & 0.025 \\
Entrepreneurial Characteristics $\rightarrow$ Entrepreneurial Competency & 0.709 & 0.000 \\
Entrepreneurial Competency $\rightarrow$ Business Performance & 0.387 & 0.002 \\
\hline
\end{tabular}

The testing of hypotheses $\mathrm{H} 1$ on the influence of the entrepreneurial characteristics of business performance indicating the result significant, indicated value standardized coefficient on relations entrepreneurial characteristics with business performance of 0,269 with probabilities ( $p$-value ) less than 0.05 . This result showing evidence that the more strong characteristic entrepreneurial the more high business performance.

Testing the hypothesis $\mathrm{H} 2$ on the influence entrepreneurial characteristics on business performance are mediated by the entrepreneurial competencies shows significant results. The relationships of entrepreneurial characteristics with entrepreneurial competencies obtained statistically significant results, demonstrated the value of the standardized coefficient of 0,709 with probability (p-value) less than 0.05. Similarly, the relationship of entrepreneurial competencies with business performance obtained statistically significant results, demonstrated the value of the standardized coefficient of 0,387 with probability ( $\mathrm{p}$-value) less than 0.05 . The results of this analysis provide evidence empirically that entrepreneurial competencies as mediation of relationship entrepreneurial characteristics with business performance.

\section{DISCUSSION}

The results of the analysis have been successfully tested empirically influence entrepreneurial characteristics on business performance, the stronger entrepreneurial characteristics of SME owners will have an impact on business performance. Entrepreneurial characteristics are the traits belonging to the small and medium business owners, comprising factors of psychology, experience, and the influence of the family, is an important factor to be owned by individuals to become entrepreneurs, only individuals who have a need for achievement and motivation that dare to start a new business by leveraging the opportunities and face the risk of failure to achieve business performance can be. These findings support previous research from Zoysa and Herath (2007); Lee and Tsang (2001); Street and Cameron (2007); Blackman (2003); Nimalathasan (2008); Solichin (2005), all of which argue the owner/manager is a key factor in the business performance. Solichin (2005) argue that entrepreneurial characteristics have a meaningful influence on the business growth, Nimalathasan (2008) argue the existence of a positive relationship between the characteristics of the owner/manager with business performance.

The results of study have been successfully tested empirically influence entrepreneurial characteristics on entrepreneurial competencies, the more powerful entrepreneurial characteristics of SME owners are able to improve the competencies. Owners of SMEs who have the need for achievement and motivation to succeed, backed with experience will be able to improve the ability of the owner to manage the organization. Relationship entrepreneurial characteristics in line with the findings of competency and Herron \& Robinson (1993) which States that the experience of employers, training, education, family background and other demographic variables are considered as factors affecting entrepreneurial competencies

Entrepreneurial competencies have significant influence on the business performance, meaning that the higher the entrepreneurial competencies of SME owners will have an effect on business performance. Owner of 
SME should have the ability to explore new ideas, take risks to work reasonably, to monitor progress towards the goals in action at risk, understanding the business implications of a wider range of ideas, have the ability of reading opportunities, establish rapport and develop a long-term relationship of mutual trust with others, ability to learn and apply it in practice management, as well as being able to identify strengths and weaknesses. If they have their competencies will an impact on the achievement of business performance. The relationship of entrepreneurial competencies with business performance supports research Man et al. (2002) entrepreneurial competencies that influence significantly to business success, as well as support Ahmad et al. (2010)

The result of the analysis provides empirical evidence that entrepreneurship competence has a mediation role relationship of entrepreneurial characteristics with business performance. Entrepreneurial characteristics are able to improve business performance through the establishment of the entrepreneurial competencies, entrepreneurial competencies will be able to further improve the business performance. Entrepreneurial characteristics of psychological factors, the experience and the influence of family is able to create entrepreneurial competency attainment. Psychological factors which include the need for achievement, and motivation will resurrect the spirit of perseverance, encouraging owners to continue to learn something new, while the experience that will benefit the owners of doing business planning, sensitive reading opportunities, establish rapport, and the role of the family will create a culture for owners to continue to learn and are always looking for ways to deal with the competition.

\section{CONCLUSION}

The results of the study illustrate that entrepreneurial competencies gives the role of business performance, the higher the competence that small and medium business owners will cause the higher business performance, as for high to low competence is determined by the characteristics of the entrepreneur. So the entrepreneurial competencies are mediating influence entrepreneurial characteristics of business performance. Increasingly strong entrepreneurial characteristics will cause the higher competence of the owner, which will ultimately lead to higher business performance.

Although research has managed to test empirically the proposed model, there are still some limitations that should be considered. First, the study only focused on SMES in the region of Malang Indonesia. Therefore, to get the results more widely, further research could develop a research location in some areas. Second, this study did not consider the demographic factors of the owners of SMEs, therefore further research might consider testing entrepreneurial characteristics based on gender differences, to find out the entrepreneurial competencies and business performance of the male and female as the owner of the SMEs.

\section{References}

[1] Ahmad, N.H., Ramayah, T., Wilson, C., and Kummerow, L. Is Entrepreneurial Competency and Business Success Relationship Contingent Upon Business Environment? A Studi of Malaysian SMEs. International Journal of Entrepreneurial Behaviour \& Research, 16(3), 2010, 182-203.

[2] Ahmad, N.H., Halim, H.A., and Zainal, S.R.M. Is Entrepreneurial Competency the Silver Bullet for SME Success in a Development Nation? International Business Management, 4(2), 2010, 67-75

[3] Beal, R.M, Competing Effectifely: Environmental Scanning Competitive Strategy And Organizational Performance: The Small Manufacturing Firms, Journal of Small Business Management, 22, 2000, 27-45.

[4] Blackman, A.J. Entrepreneurs: Interrelationships between their characteristics, values, expectations, management practices and SME performance. School of Business Department of Management Griffith University, Gold Coast Campus. (Submitted in fulfilment of the requirements of the degree of Doctor of Philosophy), 2003.

[5] Boyatzis, R.E. The Competent Manager: A Model for Effective Performance. New York: Wiley, 1982.

[6] Fagenson, E. Personal value systems of men and women entrepreneurs versus managers, Journal of Business Venturing, 8, 1993, 409-30.

[7] Ghozali, I. Model Persamaan Struktural: Konsep dan Aplikasi dengan Program Amos ver 5.0, Badan Penerbit Universitas Diponegoro, Semarang, 2005.

[8] Herron, L. and Robinson, R.B. A Structural Model of the Effects of Entrepreneurial Characteristics on Venture Performance, Journal of Business Venturing, 8(3), 1993, 281-94.

[9] Hisrich, R.D., Peter, M.P., and Shepherd, D.A., Entrepreneurship. Chriswan Sungkono dan Diana Angelica (translation), Kewirausahaan, Salemba Empat, Jakarta, 2008.

[10] Jauch, L.R. and Glueck, W.F. Business Policy and Strategic Management. Mc-Graw-Hill Books Company. Singapore, 1998.

[11] Kiggundu, M.N. Entrepreneurs and Entrepreneurship in Africa: what is known and what needs to be done, Journal of Development Entrepreneurship, 7(3), 2002, 239-258.

[12] Kotey, B. and Meredith, G.G. Relationship among owner/manager personal values and perceptions, business strategis, and enterpreise performance, Journal of Small Business Management, 35(2), 1997, 37-64

[13] Lee D.Y. and Tsang, E.W.K. The Effect of Entrepreneurial Personality, Background and Network Activities on Venture Growth, Journal of Management Studies, 38(4), 2001, 583-602.

[14] Li, H., Zhang, Y. and Chan, T.S. Entrepreneurial Strategy Making and Performance in China's New Technology Ventures - The Contingency Effect of Environment and Firm Competence, Strategic Management Journal, 16, 2005, 37-57.

[15] Li, X.. Entrepreneurial Competencies as an Entrepreneurial Distinctive: An Examination of the Competency Approach in Defining Entrepreneurs. Dissertations and Theses Collection. Institutional Knowledge at Singapore Management University, 2009.

[16] Man, M.M.K, and Wafa, S.A. Distinctive Capabilities and The Performance of Small and Medium-Size Enterprises (SMEs) in Malaysia. International Business \& Economics Research Journal, 7(6), 2008, 45-59 
[17] Man, T.W.Y. Entrepreneurial Competencies and The Performance of Small and Medium Enterprises in Hongkong Services Sector, unpublised Doctoral Thesis, Hongkong Polytechnic University, Hongkong, 2001.

[18] Man, T.W.Y., Lau, T. and Chan, K.F. The competitiveness of small and medium enterprises a conceptualization with focus on entrepreneurial competencies. Journal of Business Venturing. 17 (2), 2002, 123-142.

[19] Man, T.W.Y. and Lau T. The Contect of Entrepreneurship in Hongkong: an investigation through the patterns of entrepreneurial competencies in contrasting industrial environments, Journal of Small Business and Enterprise Development, 12(4), $2005,67-92$.

[20] Mole, V., Dawson, S., Winstanley, D., and Sherval, J. Researching managerial competencies. Paper Presented to the British Academy of Management Annual Conference. Milton Keynes, 1993.

[21] Nimalathasan, B., A Relationship Between Owner-Managers Characteristic and Business Performance, Les ET Scientia International Journal, XV(1), 2008

[22] O’Regan, N., Sims, M. \& Ghobadian, A. High performance: ownership and decision-making in SMEs. Management Decision, 43(3), 2005, 382-396.

[23] Olson, S.F. and Currie, H.M. Female entrepreneurs: personal value systems and business strategies in a male-dominated industry', Journal of Small Business Management, 30(1), 1992, 49-57.

[24] Sanchez, A.A. and Marin, G.S. Orientation Management, Characteristic, and Performance. A Study Spanish SME's, Journal of Small Business Management, 43(3), 2005, 287-306.

[25] Shane, S., Locke, E.A., and Collins, C.T. Entrepreneurial Motivation, Human Resources Management Review, 13, 2003, 25-279

[26] Shaw, E., and Conway, S. Networking and the Small Firm. Enterprise and Small Business. Ed. S. Carter and D. Jones-Evans. Harlow, UK: Financial Times/Prentice Hall, 2000.

[27] Solichin, E. Kajian Karakteristik Entrepreneurship dan Iklim Usaha serta Kontribusinya terhadap Kemajuan Usaha. Disertasi. Program Studi Ilmu Pertanian Minat Ekonomi Pertanian. Program Pascasarjana Universitas Brawijaya Malang, 2005.

[28] Sørensen, J.B. \& Chang, P.M.Y. Determinants of Successful Entrepreneurship : A Review of the Recent Literature, MIT Sloan School of Management, 2006.

[29] Street, C.T and Cameron, A.F. External Relationships and the Small Business: A Review of Small Business Alliance and Network Research, Journal of Small Business Management, 45(2), 2007.

[30] Zoysa, A. De \& Herath, S.K. The impact of owner/managers' mentality on financial performance of SMEs in Japan: An empirical investigation. Journal of Management Development, 26(7), 2007, 652-666. 